\title{
PENGARUH PENGGUNAAN DAUN KEMANGI DAN KULIT JERUK NIPIS PADA PROSES PENCUCIAN ALAT MAKAN TERHADAP ANGKA KUMAN
}

\author{
Dewi Safitri, Yusmidiarti, Elly Wahyuni \\ Politeknik Kesehatan Kementerian Kesehatan Bengkulu, Jurusan Kesehatan Lingkungan, \\ Jalan Indragiri Nomor 3 Padang Harapan Bengkulu \\ e-mail :dewi_safitri@yahoo.com
}

\begin{abstract}
The process of washing utensils in the coto stall Minggu market still not meet the standard number of germs cutlery of allowed. Water used in the washing process is physically still do not meet the requirements because of water used repeatedly without being replaced in a day. These conditions could affect the health of consumers caused by washing utensils the lack of clean and unhygienic. Basil leaves and leather lime with the flavonoid and volatile oil can reduce the number of germs cutlery.

Known effect of the use of basil leaves and leather lime in the process of washing utensils on the number of germs. Experimental studies with Posttest Only Control Group Design. Location of research conducted at the soup stall Minggu Market, of Ratu Samban District, City of Bengkulu. The subjects of this research is a leaf of basil (Ocimum sanctum) and the leather lime (Citrus aurantifolia). Research object is the number of germs cutlery. Test used is the One Way Anova. Research using 6 basil leaves and 1 small leather lime can reduce the number of germs cutlery. The One Way Anova test results are known significant value $0,028<0,05$. This means that there are significant differences between the number of bacterial colonies the control group, basil and leather lime on the number of germs cutlery.
\end{abstract}

Key Words : Basil Leaves, Lime Leather, Germs figure Dinnerware

\begin{abstract}
Abstrak : Proses pencucian alat makan di warung soto Pasar Minggu belum memenuhi standar angka kuman alat makan yang diperbolehkan. Air yang digunakan dalam proses pencucian secara fisik belum memenuhi persyaratan karena air yang digunakan secara berulang tanpa diganti dalam sehari. Kondisi ini dapat memberi dampak bagi kesehatan konsumen yang disebabkan oleh pencucian alat makan yang kurang bersih dan tidak higienis. Daun kemangi dan kulit jeruk nipis dengan kandungan flavonoid dan minyak atsiri mampu menurunkan angka kuman alat makan.

Diketahui pengaruh penggunaan daun kemangi dan kulit jeruk nipis pada proses pencucian alat makan terhadap angka kuman Studi eksperimen dengan Posttest Only Control Group Design. Lokasi penelitian dilakukan di warung soto Pasar Minggu, Kecamatan Ratu Samban, Kota Bengkulu. Subyek penelitian adalah daun kemangi (Ocimum sanctum) dan kulit jeruk nipis (Citrus aurantifolia). Objek penelitian adalah angka kuman alat makan. Uji yang digunakan adalah One Way Anova. Penelitian menggunakan 6 lembar daun kemangi dan 1 buah kulit jeruk nipis mampu menurunkan angka kuman alat makan.

Hasil uji One Way Anova diketahui nilai signifikan 0,028 < 0,05. Artinya ada perbedaan yang signifikan antara jumlah koloni bakteri kelompok kontrol, daun kemangi dan kulit jeruk nipis terhadap angka kuman alat makan.
\end{abstract}

Kata Kunci : Daun Kemangi, Kulit Jeruk Nipis, Angka Kuman Alat Makan

Makanan merupakan bagian yang penting untuk kesehatan manusia mengingat setiap saat dapat saja terjadi penyakit-penyakit yang diakibatkan oleh makanan. Kasus penyakit bawaan makanan (food borne disease) dapat dipengaruhi oleh berbagai faktor. Faktor-faktor tersebut antara lain kebiasaan mengolah makanan secara tra- disional, penyimpanan dan penyajian yang tidak bersih serta tidak memenuhi persyaratan sanitasi (Chandra, 2006).

Menurut Peraturan Menteri Kesehatan Nomor 942/Menkes/SK/VII/2003 tentang syaratan hygiene sanitasi makanan jajanan dan menurut UU Nomor 7 tahun 1996 tentang pangan disebutkan bahwa sanitasi 
pangan adalah upaya pencegahan terhadap tumbuh dan berkembangnya jasad renik pembusuk dan pathogen dalam makanan, minuman, peralatan dan bangunan yang dapat merusak pangan dan dapat membahayakan kesehatan manusia. Pengertian di atas menyebutkan bahwa media yang dapat digunakan untuk tumbuh dan berkembangnya jasad renik adalah peralatan baik itu peralatan mengolah, menyajikan, menjual makanan maupun peralatan makan, sehingga untuk mencegah jasad renik perlu dilakukan pencucian peralatan sampai bersih dan steril.

Melihat banyaknya jumlah kasus diare di Kota Bengkulu yang dimungkinkan disebabkan oleh para pedagang warung makan maka sudah menjadi perhatian yang sangat serius oleh berbagai pihak terutama pemerintah. Berdasarkan pertimbangan dan pentingnya pengawasan makanan dan alat makan, maka penulis menggunakan daun kemangi dan kulit jeruk nipis sebagai bahan penelitian dalam pencucian alat makan terhadap angka kuman, menggunakan daun kemangi dan kulit jeruk nipis pada proses pencucian alat makan. Diharapkan daun kemangi dan kulit jeruk nipis dapat membunuh dan menghilangkan kuman pada alat makan pedagang soto, sehingga dengan hasil penelitian kemangi dan kulit jeruk nipis selain sebagai lalapan dan penyedap rasa juga dapat digunakan sebagai bahan pengganti sabun cuci alat makan.

Menurut Mangoting et al. (2005), kemangi merupakan anggota famili Lamiaceae yang berarti kelompok tanaman bunga berbibir. Nama genus kemangi adalah Ocimum yang berarti tanaman beraroma. Aroma khas tersebut muncul dari daunnya.

Menurut Laliyanto (2009), beberapa klaim tradisional telah dibuktikan secara ilmiah dengan pengujian farmakologi, bahwa senyawa bioaktif yang terdiri dari kamfor, d-limonen, mirsen, metilkavikol dan eugenol merupakan senyawa penyusun minyak atsiri. Kemangi telah diuji mempunyai aktivitas antibakteri, antifungi, larvasida, antiulcer dan antiseptik. Hasil penelitian memperlihatkan bahwa kan- dungan d-limonen, mirsen, metilkalvikol dan augenol merupakan penyusun minyak atsiri yang menghambat pertumbuhan aureus bakteri Staphylococcus, Salmonella enteridis dan Eschericia coli, bahkan kemangi dapat menangkal infeksi yang disebabkan oleh virus seperti Bacillus subktulis, Salmonella paratyphy dan Proteus vulgaris.

Sedangkan jeruk nipis Menurut Kamus Pertanian Umum (2005), adalah jenis-jeruk yang buahnya banyak mengandung air, rasa sangat masam dengan aroma sangat sedap, banyak mengandung asam sitrat. Menurut Sarwono (1991), jeruk nipis merupakan anggota famili rutaceae, nama genusnya adalah citrus. Jeruk nipis termasuk jenis tumbuhan perdu yang banyak memiliki dahan dan ranting. Jeruk nipis juga mengandung zat antibakteri yang berperan menghambat pertumbuhan angka kuman alat makan, zat antibakteri yang berperan membunuh kuman adalah minyak atsiri (sitral, limonen, felandren, lemon, kamfer, kadinen, gerani-lasetat, linali-lasetat, aktilaldehid dan nildehid), minyak terbang (limonene dan linalool) dan flavonoid, seperti poncirin, hesperidine, rhoifolin dan naringin.

\section{BAHAN DAN CARA KERJA}

Ini merupakan penelitian eksperimen. Penelitian eksperimen atau percobaan adalah penelitian dengan melakukan percobaan yang bertujuan untuk menguji hipotesis sebab akibat dengan melakukan intervensi (Notoatmodjo, 2010). Penelitian ini bersifat deskriptif dengan analisis laboratorium untuk mengetahui perbedaan penggunaan daun kemangi dan kulit jeruk nipis terhadap angka kuman yang terdapat pada alat makan yang digunakan oleh pedagang soto di Pasar Minggu Kota Bengkulu.

Desain atau rancangan penelitian "Posttest Only Control Group Design" (Notoatmodjo, 2010). 
HASIL

Hasil pemeriksaan laboratorium antara kelompok kontrol dibandingkan kelompok perlakuan 1 dan kelompok perlakuan. Dari hasil pemeriksaan laboratorium, masingmasing perlakuan kemudian disajikan ke dalam bentuk tabel 1:

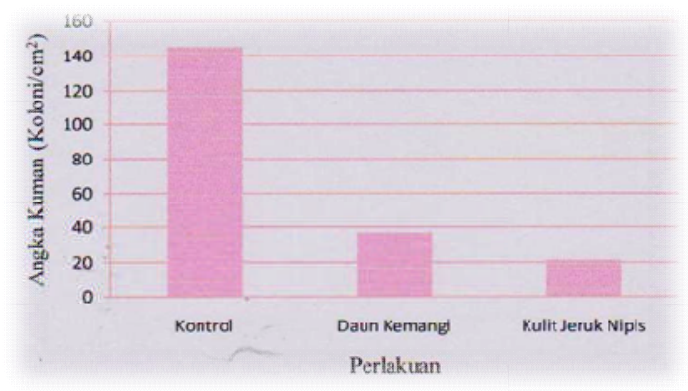

Gambar 1 Hasil Rerata Angka Kuman Alat Makan pada Perlakuan Kontrol, Daun Kemangi dan Kulit Jeruk Nipis

Pada Gambar 1 dapat dilihat rerata angka kuman pada kontrol adalah 145 koloni/cm2, perlakuan menggunakan 6 lembar daun kemangi adalah 36,67 koloni/cm2 dan perlakuan menggunakan kulit jeruk nipis adalah 21,33 koloni/cm2.

Tabel 1 Efektifitas Penurunan Angka Kuman Alat Makan pada Perlakuan Daun Kemangi dan Kulit Jeruk Nipis

\begin{tabular}{ll}
\hline \multicolumn{1}{c}{ Perlakuan } & \multicolumn{1}{c}{$\begin{array}{c}\text { Efektifitas Penurunan } \\
\text { Angka Kuman (\%) }\end{array}$} \\
\hline Daun Kemangi & \multicolumn{2}{c}{74,71} \\
Kulit Jeruk Nipis & 85 \\
\hline
\end{tabular}

Tabel 2 Pengaruh Penggunaan Daun Kemangi dan Kulit Jeruk Nipis terhadap Angka Kuman Alat Makan

\begin{tabular}{llll}
\hline \multicolumn{1}{c}{ Perlakuan } & \multicolumn{1}{c}{$\begin{array}{c}\text { Rerata } \\
\text { Koloni }\end{array}$} & Ket & P value \\
\hline Kontrol & 145 & $\mathrm{a}$ & 0,028 \\
Daun Kemangi & 36,67 & $\mathrm{~b}$ & \\
Kulit Jeruk Nipis & 21,33 & $\mathrm{~b}$ & \\
\hline
\end{tabular}

Skor rerata yang ditandai dengan huruf yang berbeda menunjukkan ada perbedaan nyata pada taraf $5 \%$ menurut uji LSD (P). Skor rerata yang ditandai dengan huruf yang sama menunjukkan tidak ada perbedaan nyata pada taraf 5\% menurut uji LSD (P).
Rerata jumlah koloni bakteri pada piring tanpa perlakuan adalah 145 koloni/cm2 dan pada uji LSD diketahui bahwa tidak ada pengaruh perlakuan kontrol terhadap penurunan angka kuman alat makan. Rerata jumlah koloni bakteri pada piring dengan perlakuan penggosokan menggunakan daun kemangi adalah 36,67 koloni/cm2 dan pada uji LSD diketahui bahwa ada pengaruh penggunaan daun kemangi terhadap penurunan angka kuman alat makan. Rerata jumlah koloni bakteri pada piring dengan perlakuan pembilasan menggunakan kulit jeruk nipis adalah 21,33 koloni/cm2 dan pada uji LSD dketahui bahwa ada pengaruh penggunaan kulit jeruk nipis terhadap penurunan angka kuman alat makan.

Hasil uji statistik didapat nilai $\mathrm{p}=$ 0,028 berarti pada alpha $5 \%$, ada perbedaan signifikan antara jumlah koloni bakteri kelompok kontrol, daun kemangi dan kulit jeruk nipis terhadap angka kuman alat makan.

\section{PEMBAHASAN}

Berdasarkan hasil analisis secara statistik diketahui bahwa rerata angka kuman yang berhasil diturunkan dari penelitian yang dilakukan dengan perlakuan menggunakan 6 lembar daun kemangi sebanyak 36,67 koloni/cm2, dengan persentase sebesar 74,71\%. Dipertegas dengan uji One Way Anova dan LSD bahwa ada pengaruh penggunaan daun kemangi terhadap penurunan angka kuman alat makan.

Berdasarkan penelitian yang dilakukan dengan perlakuan menggunakan 1 buah kulit jeruk nipis didapatkan hasil dengan rerata angka kuman yang berhasil diturunkan sebanyak 21,33 koloni/cm2, dengan persentase sebesar 85\%. Dipertegas dengan uji One Way Anova dan LSD bahwa ada pengaruh penggunaan kulit jeruk nipis terhadap penurunan angka kuman alat makan.

Angka kuman yang berhasil diturunkan menggunakan 1 buah kulit jeruk 
nipis karena adanya kandungan minyak atsiri, minyak terbang, asam amino, asam sitrat dan zat flavonoid. Penelitian ini sejalan dengan teori Sarwono (2001) bahwa kegunaan jeruk nipis selain untuk pengobatan juga untuk membersihkan alatalat dapur dan sarana rumah tangga.

Berdasarkan hasil analisis secara statistik diketahui bahwa penggosokan menggunakan 6 lembar daun kemangi dan pembilasan menggunakan kulit jeruk nipis memiliki hasil yang berbeda-beda antara variasi variabel yang digunakan dalam pencucian alat makan, ini mengindikasikan bahwa perbedaan hasil tersebut karena menggunakan 6 lembar daun kemangi dan kulit jeruk nipis memiliki kandungan zat antibakteri yang berbeda. Menggunakan 6 lembar daun kemangi itu lebih sedikit mempunyai kandungan zat antibakteri dibandingkan menggunakan kulit jeruk nipis. Perbedaan sedikit banyaknya kandungan zat antibakteri yang dikandung oleh daun kemangi dengan kulit jeruk nipis pada masing-masing perlakuan terbukti mempengaruhi hasil penelitian ini.

Hasil uji menggunakan One Way Anova diketahui bahwa nilai $\mathrm{p}=0,028$ dengan kemaknaan $(\alpha) 0,05$, berarti ada pengaruh penggunaan daun kemangi dan kulit jeruk nipis pada proses pencucian alat makan terhadap angka kuman. Ada perbedaan rerata angka kuman alat makan yang digosok dengan 6 lembar daun kemangi maupun dibilas dengan kulit jeruk nipis, untuk mengetahui hasil penurunan angka kuman yang paling efektif kemudian dilakukan memakai uji LSD.

Berdasarkan hasil uji LSD diketahui bahwa antara perlakuan menggunakan 6 lembar daun kemangi dengan 1 buah kulit jeruk nipis didapatkan nilai signifikansi $0,687>0,05$, artinya tidak ada beda antara menggunakan 6 lembar daun kemangi dengan 1 buah kulit jeruk nipis terhadap angka kuman alat makan. Untuk menentukan penggunaan yang paling efektif kemudian dilihat dari persentase penurunan angka kuman alat makan antara menggunakan daun kemangi dan kulit jeruk nipis dalam menurunkan angka kuman alat makan.

Penurunan angka kuman tertinggi adalah menggunakan 1 buah kulit jeruk nipis dengan persentase penurunan $85 \%$, penurunan angka kuman terendah menggunakan 6 lembar daun kemangi yaitu dengan persentase penurunan sebesar $74,71 \%$. Penggunaan yang paling efektif untuk menurunkan angka kuman adalah menggunakan 1 buah kulit jeruk nipis, karena persentase penurunannya paling tinggi dibandingkan menggunakan 6 lembar daun kemangi.

Setelah dilakukan penelitian menggunakan 6 lembar daun kemangi dan 1 buah kulit jeruk nipis terlihat mampu menurunkan angka kuman alat makan dan memenuhi baku mutu angka kuman yang dianjurkan untuk peralatan makan 100 koloni/cm2 menurut Abdullah (2009), Laliyanto (2009) dan Permenkes RI No. 715/Menkes/PER/2003 tentang persyaratan hygiene industri jasa boga. Daun kemangi dan kulit jeruk nipis yang digunakan sebagai desinfektan terhadap angka kuman alat makan sangat mendukung proses penelitian ini dan dihasilkan proses pencucian yang optimal yaitu memenuhi standar persyaratan angka kuman peralatan alat makan yang telah ditetapkan.

Aplikasi hasil penelitian dengan judul Pengaruh Penggunaan Daun Kemangi (Ocimum sanctum) dan Kulit Jeruk Nipis (Citrus aurantifolia) pada Proses Pencucian Alat Makan terhadap Angka Kuman di Warung Soto Pasar Minggu Kota Bengkulu Tahun 2012 ini dapat dipakai sebagai disinfektan yang menurunkan angka kuman alat makan dengan mensosialisasikan kepada pedagang warung soto tentang manfaat daun kemangi dan kulit jeruk nipis yang dapat menurunkan angka kuman alat makan. Mensosialisasikan hasil penelitian juga dilakukan dengan memperlihatkan harga yang relatif murah, pedagang warung soto dapat menggunakan daun kemangi dan kulit jeruk nipis sebagai bahan untuk mencuci alat makannya. Daun kemangi dan kulit 
jeruk nipis bisa menghemat dan mengurangi volume sampah yang merupakan bagian dari bahan lalapan maupun penyedap rasanya.

\section{KESIMPULAN}

Rerata persentase penurunan angka kuman alat makan pada perlakuan penggosokan dengan menggunakan daun kemangi adalah $74,71 \%$. Rerata persentase penurunan angka kuman alat makan pada perlakuan pembilasan menggunakan kulit jeruk nipis adalah 85\%. Pengaruh penggunaan daun kemangi dan kulit jeruk nipis terhadap angka kuman alat makan di warung soto Pasar Minggu yaitu dengan nilai signifikan $0,028<0,05$. Berdasarkan uji LSD tidak ada beda antara meng-

\section{DAFTAR RUJUKAN}

Acandra. 2010. Inilah 26 Khasiat Jeruk Nipis. Diunduh $30 \quad$ Desember 2011.Darihttp://health.kompas.com/read/2010 /08/04/09093083/Inilah.26.Khasiat.Jeruk. Nipis.

Abdullah, Sugeng. 2009. Alat Makan Lolos Uji Sanitasi. Diunduh $21 \quad$ Maret 2012.Darihttp://sugeng zend.blogspot.com/2009/02/ alat-makan-lolosui sanitasi.html.

Andriyani, Annisa. 2009. Efektivitas Penurunan Jumlah Angka Kuman Alat Makan dan Efisiensi Biaya yang Digunakan pada Metode Pencucian Alat Makan di Rumah Sakit Kota Surakarta. Jurnal Gizi Klinik Indonesia. Vol. 6. No. $1: 35-41$.

Asfarnuryadin . 2005. Studi Komparatif Angka Kuman Peralatan Makan dan Faktor-faktor yang Mempengaruhi pada Rumah Makan Grade $B$ dan $C$ di Kota Manado. Jurnal Lembaga Pengabdian kepada MasyarakatUniversitas Gadjah Mada.

Candra, Asep. 2011. Memetik Manfaat Daun Kemangi. Diunduh 15 Februari 2012. Dari http://health.kompas.com/read/2011/09/28/10 560749/ Memetik.Manfaat.Daun.Kemangi.

Chandra, Budiman. 2006. Pengantar Kesehatan Lingkungan. EGC. Jakarta.

Departemen Kesehatan RI. 2003. Peraturan Menteri Kesehatan Nomor : 942/MenKes/SK/VII/2003 Tentang Pedoman Persyaratan Hygiene Sanitasi Makanan Jajanan. Departemen Kesehatan RI. Jakarta. gunakan 6 lembar daun kemangi dibanding 1 buah kulit jeruk nipis terhadap angka kuman alat makan. Berdasarkan persentase penurunan angka kuman alat makan ada perbedaan antara penggunaan jumlah Rerata penurunan angka kuman alat makan, dibanding selisih tipis yaitu sebanyak $10,29 \%$.

Diharapkan agar menginformasikan hasil penelitian sebagai khasanah ilmu pengetahuan kesehatan lingkungan khususnya mengenai penyehatan makanan dan minuman. Sebaiknya menggunakan sisa daun kemangi dan kulit jeruk nipis sebagai desinfektan dalam pencucian alat makan, sehingga dapat menghambat pertumbuhan angka kuman alat makan.

Dinas Kesehatan Kota Bengkulu. 2010. Profil Kesehatan Kota Bengkulu Tahun 2009”. Dinkes Kota Bengkulu. Bengkulu.

Dinas Kesehatan Kota Bengkulu 2011. Profil Kesehatan Kota Bengkulu Tahun 2010. Dinkes Kota Bengkulu. Bengkulu.

Endah. 2011. Pemeriksaan Angka Kuman. Diunduh $21 \quad$ Maret 2012.Darihttp://endahsss.blogspot.com2011/0 6/laporan-praktikum-mikrobiologi.html.

Kemenkes RI. 1996. Undang-undang Nomor 7 Tahun 1996 Tentang Pangan. Kemenkes RI. Jakarta.

Laliyanto. 2009. Pengaruh Penggunaan Daun Kemangi (Ocimum sanctum) pada Proses Pencucian Alat Makan terhadap Angka Kuman di Warung Makan Pecel Lele. Poltekkes Depkes RI Yogyakarta. Yogyakarta.

Manfaat Jeruk Nipis. Diunduh 30 Desember 2011. Dari http://afghanaus.com/manfaat-jeruknipis/.

Maloha, Ma'as M. 2002. Pemeriksaan Angka Kuman Escherechia Coli dengan Usap Alat pada Restoran, Rumah Makan dan Lokalisasi Makanan Jajanan di Kota Jambi Tahun 2001. Universitas Sumatera Utara. Medan.

Mangoting, Daniel et. al. 2005. Tanaman Lalapan Berkhasiat Obat. Penebar Swadaya. Jakarta.

Notoatmodjo, Soekidjo. 2010. Metodologi Penelitian Kesehatan. Rineka Cipta. Jakarta.

Proyo, Sutanto Hastono. 2006. Basic Data Analysis for Health Research. Universitas Indonesia. Jakarta.

Pohan, Desmaslima. 2009. Pemeriksaan Escherichia Coli pada Usapan Peralatan 
Makan yang Digunakan Oleh Pedagang Makanan di Pasar Petisah Medan tahun 2009. Universitas Sumatera Utara. Medan.

Purnawijayanti, Hiasinta A. 2001. Sanitasi Higiene dan Keselamatan Kerja dalam Pengolahan Makanan. Kanisius. Yogyakarta.

Saksono, Lukman. 1986. Pengantar Sanitasi Makanan. P.T. Alumni. Bandung.

Sarwono, B. 2001. Khasiat \& Manfaat Jeruk Nipis. ArgoMedia Pustaka. Jakarta.

Sarwono, B. 1991. Jeruk Nipis dan Pemanfaatannya. Penebar Swadaya. Jakarta.
Suyono dan Budiman. 2010. Ilmu Kesehatan Masyarakat dalam Konteks Kesehatan Lingkungan. EGC. Jakarta.

Tim Penyusun Kamus PS. 2005. Kamus Pertanian Umum. Penebar Swadaya. Jakarta.

Yunita, Ni Luh Payastiti dan Ni Made Utami Dwipayanti. 2010. Kualitas Mikrobiologi Nasi Jinggo Berdasarkan Angka Lempeng Total, Coliform Total dan Kandungan Escherichia coli. Jurnal Biologi. Vol. XIV. No. 1 : 15-19. 